\title{
The Influence of Vasoconstritor Use in Local Anesthesia in Individuals with Chronic Renal Failure
}

\section{A Influência do Uso de Vasoconstritor na Anestesia Local em Indivíduos com Insuficiência Renal Crônica}

\author{
Andrei Rosa ${ }^{a}$; Natalino Francisco da Silva ${ }^{a}$; Alex Semenoff Segundo ; Tereza Delle Vedove Semenoff ; \\ Alvaro Henrique Borges*aa Alexandre Meireles Borba ${ }^{\mathrm{a}}$ \\ ${ }^{a}$ University of Cuiabá, Stricto Sensu Graduate Program in Integrated Dental Sciences. MT, Brazil. E-mail: College of Sinop.

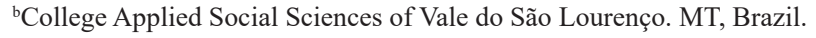 \\ 'Private Dental's Office MT, Brazil. \\ *E-mail: alvaro.borges@kroton.com.br \\ Recebido em: 04/02/19 \\ Aprovado em: 02/08/19
}

\begin{abstract}
Individuals with chronic renal failure (CRD) undergo hemodialysis to compensate for systemic-based disease and often develop systemic arterial hypertension (SAH). Such individuals, when needing dental treatment, carry with them the consideration of which type of anesthetic to be used in clinical and surgical interventions. The objective of this study was to evaluate the action of anesthetics with vasoconstrictor $(\mathrm{AwV})$ and without vasoconstrictor $(\mathrm{AoV})$ in individuals with chronic renal failure. Research subjects needed dental treatment, with dental restorations, on the right and left lower dental arch in premolars and / or molars, thus receiving the model of a split-mouth clinical study. In a randomized study, each side of the mandible was subjected to an anesthetic infiltration with only one $1.8 \mathrm{~mL}$ tube in two different moments with a minimum interval of 7 days (for one moment with $\mathrm{AwV}$ and another $\mathrm{AoV}$ moment). The parameters of oxygen saturation (SaO2), heart rate (HR), systolic blood pressure (SBP) and diastolic blood pressure (DBP) were measured 5 minutes before anesthesia, 5, 15 and 30 minutes after anesthesia. The results found in this study showed statistical difference only in $\mathrm{SaO} 2$ in the time of 5 minutes after the anesthesia in comparison of the $\mathrm{AwV}$ and AoV group, this same result was obtained when only those individuals who, besides nephropathies, had a diagnosis of SAH, were evaluated. The findings of this study highlight the safety of the use of anesthetics, with or without vasoconstrictors since in small amounts, in individuals with CRF with or without associated SAH.
\end{abstract}

Keywords: Renal Insufficiency. Hypertension. Anesthetics, Local.

\section{Resumo}

Indivíduos com insuficiência renal crônica (IRC) em geral são submetidos à hemodiálise para compensação da doença de base sistêmica e frequentemente desenvolvem a hipertensão arterial sistêmica (HAS). Tais indivíduos, ao necessitarem de tratamento odontológico, levam consigo a ponderação de qual tipo de anestésico a ser utilizado em intervenções clínicas e cirúrgicas. O objetivo deste estudo foi avaliar a ação de anestésicos com vasoconstritor (ACV) e sem vasoconstritor (ASV) em indivíduos com insuficiência renal crônica. Os indivíduos da pesquisa tinham necessidade de tratamento odontológico, com restaurações dentárias, no arco dentário inferior direito e esquerdo em pré-molares el ou molares, recebendo assim o modelo de estudo clínico de boca dividida. De forma aleatória, os hemiarcos inferiores foram submetidos, em dois diferentes momentos com intervalo mínimo de 7 dias, a infiltração anestésica com apenas um tubete de 1,8 $\mathrm{mL}$ (para um momento com ACV e outro momento ASV). Foi feita aferição dos parâmetros de saturação de oxigênio (SaO2), frequência cardiaca (FC), pressão arterial sistólica (PAS) e diastólicas (PAD), 5 minutos antes da anestesia, 5, 15 e 30 minutos após a anestesia. Os resultados encontrados neste estudo demonstraram diferença estatística apenas na SaO2 no tempo de 5 minutos após a anestesia em comparação do grupo ACV e ASV, esse mesmo resultado foi obtido quando avaliados apenas os individuos que, além de nefropatas, apresentavam diagnóstico de HAS. Os achados deste estudo ressaltam a segurança do uso de anestésicos, com ou sem vasoconstritores desde que em pequenas quantidades, em indivíduos com IRC com ou sem HAS associada.

Palavras-chave: Insuficiência Renal. Hipertensão. Anestésicos Locais.

\section{Introduction}

Chronic renal failure (CRF) has been considered a public health problem, affecting more than $7 \%$ of the world population, from 20 to 59 years $^{1.2}$ The renal disease is classified in accordance with the stages of severity of glomerular filtration rate (TGF). The IRC is the most advanced stage of the disease and consists of the gradual, irreversible and multifactorial loss of renal, urinary and endocrine function to maintain the metabolic and hydro electrolytic balance, generating changes in various body systems ${ }^{3}$.
The IRC leads to systemic problems such as DM and hypertension and this association can lead to other systemic problems that lead to the worsening of the individual. Hypertension is the most prevalent comorbidity among the diseases developed in HD treatment for individuals with this IRC ${ }^{4-7}$. Individuals with CRF need health care, avoiding infectious processes and which may compromise their homeostasis, especially in individuals who undergo surgery for renal transplantation ${ }^{8}$.

Severe systemic diseases, such as kidney diseases, are risk factors for injury or tooth loss, in this sense, the oral 
cavity in this group of patients has received great attention by professionals who deal with the IRC, especially individuals who undergo hemodialysis (HD), because the infections present at this location can affect the whole body ${ }^{9}$. Individuals with CRF should make dental monitoring for treating or preventing oral health problems as carious lesions, periodontal disease and tooth loss ${ }^{10.11}$ for this, it is crucial the assiduity to the dentist for control of oral microbiota ${ }^{12}$.

Individuals with $\mathrm{CRF}$ often have $\mathrm{SAH}$, which determines a more careful choice of anesthetics to be used ${ }^{2,5-7}$. Due to the need of dental care, the dental surgeon, requires the use of local anesthetics for the realization of various procedures the choice of anesthetic to be used should consider the anesthetic potency, latency (time of onset of anesthesia), duration of the anesthetic effect, the pharmacokinetics (absorption, distribution, metabolism and excretion) and toxicity ${ }^{13}$. The anesthetic injection associated with the use of vasoconstrictors in dentistry can lead to changes in diastolic blood pressure (DBP) and systolic blood pressure (SBP) between the period before anesthetic induction and the stabilization period ${ }^{14}$.

The injection of anesthetics with vasoconstrictors may cause significant increase of BP, this way one must be cautious to administer this anesthetic combination to cardiovascular individuals ${ }^{14}$. Knowing that local anesthetics cause systemic effects and due to lack of information related to these effects after anesthetic injection site in the group of individuals with CRF who commonly has the $\mathrm{SAH}$ associated, it is advisable to conduct studies to assess the effects caused by these substances. Therefore, it is proposed retrospective measurement of multiparameter repercussion of local anesthesia, associated or not to vasoconstrictor, in individuals with CRF.

\section{Material and Methods}

This study translates into a clinical trial in a model of mouth divided carried out at University of (UNIC) between March 2017 and January 2018. The research participants were characterized by individuals with CRF undergoing treatment for HD by Renal Treatment Clinic - CTR (Cuiabá - MT), referenced to dental care dental clinic of the College of Dentistry of UNIC. This study is part of a research project approved by the Committee for Ethics in Research of the UNIC under record No. 21 CEP/UNIC - protocol 2011-021.

Inclusion criteria were listed as nephropathic patients diagnosed in stage 5 (renal failure requiring dialysis or transplantation for survival, with TGF estimated $<15 \mathrm{~mL} /$ min per 1.73), in HD for more than six months, aged over 18 years who needed dental intervention for dental restorations or exchange of simple cavity restorations in pre-molars or lower molars. Exclusion criteria were determined by systemic instability that did not allow dental insurance, the non-acceptance to dental treatment proposed, or the need to use more than one anesthetic cartridge (volume of $1.8 \mathrm{~mL}$ per cartridge) for intervention. Eligible individuals were grouped in group IRC. IRC group individuals with concomitant diagnosis of SAH, were secondarily subdivided in IRC group with SAH.

The dental diagnosis was done by means of physical examination and radiographic testing of pulp vitality in the teeth to be treated. The service was done in two visits, following the model of split mouth, being performed the anesthesia of the IAN block technique to perform the procedure necessary in each one of the sessions.

The technique used for the IAN block was the direct block, initially performed by the identification of the lines formed by the ascending branch and the pterygomandibular ligament and outlining the bisection of the angle of these lines; the carpule syringe was positioned between the pre-molars on the side opposite one centimeter above the occlusal plan with the bevel of the needle facing the inner face of the branch of the mandible and starting the puncture as it penetrates into the tissue to insert the needle until this touched the bone. Then, the needle was backed one centimeter, and it was observed the absence of blood reflux, and the remainder of the anesthetic was injected ${ }^{15}$.

As outcome variable, two different types of anesthetics were used, one for each intervention. The group of local anesthetics with vasoconstrictor (ACV) was determined using $2 \%$ mepivacaine with epinephrine 1:100,000 (MEPIADRE, mepivacaine hydrochloride $36 \mathrm{mg}+$ epinephrine $18 \mathrm{ug}$ ) while the group of anesthetics without vasoconstrictor (ASV) 3\% mepivacaine was used without vasoconstrictor (MEPIASV, mepivacaine hydrochloride $54 \mathrm{mg}$ / without vasoconstrictor).

The hemi-arch choice to be treated first, and the anesthetic to be used in each session (group ACV or ASV) was performed by means of a draw with a coin, promoted by the same assistant who was responsible for the data collection and by masking the operator knowledge in relation to the anesthetic to be used. This masking was done using gloves for carpule syringe, delivered to the researcher already prepared with the anesthetic and with long needle. In the second session of each individual, the antagonist side was worked and it was used another anesthetic, even without the knowledge of both the individual and the operator.

Prior to and during both interventions, the parameters for SBP and DBP were measured with the digital arm automatic pressure apparatusML303 G-TECH being observed to assess the individual's arm with IRC where there was not the arteriovenous fistula used to HD. Also, the heart rate (HR) and arterial oxygen saturation of hemoglobin $\left(\mathrm{SaO}_{2}\right)$ were evaluated with the finger oximeter (G-TECH). All parameters were recorded, with the aid of a stopwatch, in times of $0,5,15$ and 30 minutes after anesthetic injection.

At each of the sessions prior to the anesthetic technique an initial rating was performed (T0) of SBP, DBP, HR and $\mathrm{SaO}_{2}$ followed then with the anesthetic technique and after 5 minutes a new measurement was performed (T5), 15 and 30 
minutes after the anesthetic technique, it was measured again (T15 and T30).

Carious lesion or unsatisfactory restoration was removed, and the new dental restoration was performed using composite resin $(\mathrm{Z} 250$ - 3M). The subjects requiring more invasive treatment such as endodontic treatment, tooth extractions, periodontal treatment, profound or very profound restorations, were forwarded to the project of care for chronic renal individuals but were not included in this assessment.

The data were collected and classified in a database in Excel for further statistical and descriptive analysis of the influence of the type of anesthetic in the parameters of SBP, DBP, HR, and $\mathrm{SaO}_{2}$, both for the IRC group and for the group IRC with SAH. The statistical analysis was performed by the QuickCalcs Software (GraphPad Software, La Jolla, CA, USA) using the paired $t$ test.

\section{Results and Discussion}

Among the 23 eligible individuals to THE research, three were excluded for various reasons, finalizing the final sample with 20 individuals in group IRC. The average age of the sample was $47.85 \pm 9.76$ years. It was observed that $75 \%$ (15) were men and only $1(5 \%)$ individual made use of alcoholic beverage. In their majority, individuals were affected by hypertension $70 \%$ (14), comprising the subdivision of the group of CRF with SAH and DM 85\% (17) (Table 1).

Table 1 - Epidemiological data of the sample.

\begin{tabular}{|c|c|c|c|c|}
\hline Variable & \multicolumn{4}{|c|}{ Group of individuals IRC } \\
\hline \multirow{3}{*}{ Gender } & Categories & $\mathrm{N}$ & \multicolumn{2}{|c|}{$\%$} \\
\hline & Male & 15 & \multicolumn{2}{|c|}{75} \\
\hline & Female & 5 & \multicolumn{2}{|c|}{25} \\
\hline \multirow{2}{*}{ Alcoholic } & Yes & 1 & \multicolumn{2}{|c|}{5} \\
\hline & No & 19 & \multicolumn{2}{|c|}{95} \\
\hline \multirow{2}{*}{ SAH } & Yes & 14 & \multicolumn{2}{|c|}{70} \\
\hline & No & 6 & \multicolumn{2}{|c|}{30} \\
\hline \multirow{2}{*}{ DM } & Yes & 17 & \multicolumn{2}{|c|}{85} \\
\hline & No & 3 & \multicolumn{2}{|c|}{15} \\
\hline \multirow{2}{*}{$\begin{array}{l}\text { Age (in } \\
\text { years) }\end{array}$} & Average & \pm & Minimum & Maximum \\
\hline & 47.85 & 9.76 & 37 & 72 \\
\hline
\end{tabular}

CRF - Chronic Renal Failure; SAH- Systemic arterial hypertension-diabetes mellitus; $\mathrm{N}$ - number of individuals; \% - Percentage.

Source: Data from the survey.

The evaluation of the parameters of $\mathrm{HR}, \mathrm{SaO}_{2}, \mathrm{SBP}$ and DBP in individuals with CRF compared to the presence or absence of vasoconstrictor in local anesthetics has resulted in statistical significance only to the variable $\mathrm{SaO}_{2}$ at time $\mathrm{T} 5$ of measurement, with an average of oxygenation increased when used local anesthetic with vasoconstrictor (Table 2).
Table 2 - Average and standard deviation for the variables of the study - IRC group $(\mathrm{n}=20)$.

\begin{tabular}{|c|c|c|c|c|c|c|}
\hline & & \multicolumn{4}{|c|}{ Anesthetic } & \multirow{3}{*}{ Significance } \\
\hline & \multicolumn{2}{|c|}{$\mathrm{ACV}$} & \multicolumn{2}{|c|}{ ASV } & \multirow[b]{2}{*}{ DP } & \\
\hline \multicolumn{2}{|c|}{ Variable } & Average & DP & Average & & \\
\hline \multirow{4}{*}{ FC } & T0 & 75.90 & 11.25 & 75.10 & 12.18 & 0.7163 \\
\hline & T5 & 76.55 & 11.50 & 75.50 & 13.06 & 0.5148 \\
\hline & T15 & 75.60 & 11.73 & 74.85 & 11.17 & 0.7656 \\
\hline & T30 & 76.35 & 11.93 & 74.40 & 11.64 & 0.3059 \\
\hline \multirow{4}{*}{$\mathrm{SaO}_{2}$} & T0 & 96.90 & 2.73 & 97.25 & 1.12 & 0.5822 \\
\hline & T5 & 97.15 & 1.95 & 96.30 & 1.92 & 0.0433 \\
\hline & T15 & 97.30 & 1.92 & 96.55 & 1.96 & 0.0917 \\
\hline & T30 & 97.10 & 2.47 & 96.90 & 1.48 & 0.7157 \\
\hline \multirow{4}{*}{ PAS } & T0 & 140.90 & 28.33 & 133.85 & 29.15 & 0.1334 \\
\hline & T5 & 144.50 & 29.20 & 135.05 & 28.39 & 0.0632 \\
\hline & T15 & 142.05 & 27.11 & 135.40 & 27.10 & 0.0923 \\
\hline & T30 & 144.60 & 29.32 & 137.15 & 25.78 & 0.0642 \\
\hline \multirow{4}{*}{ PAD } & T0 & 82.00 & 12.83 & 77.90 & 18.50 & 0.1145 \\
\hline & T5 & 81.05 & 15.06 & 79.35 & 17.77 & 0.5639 \\
\hline & T15 & 81.40 & 13.64 & 81.15 & 16.90 & 0.9292 \\
\hline & T30 & 84.40 & 15.49 & 80.50 & 16.00 & 0.0672 \\
\hline
\end{tabular}

ACV - local anesthetic with vasoconstrictor; ASV - anesthetic without vasoconstrictor; HR-Heart rate; $\mathrm{SaO}_{2}$ - oximetry; PAS - systolic blood pressure; DBP - Diastolic Blood Pressure; SD - Standard Deviation; T0 - initial time, T5 - 5 minutes after anesthesia; T15 - 15 minutes after anesthesia; T30 - 30 minutes after anesthesia. Significance with $\mathrm{P}<0.05$ by paired $\mathrm{t}$ test.

Source: Data from the survey.

When analyzing only the group of CRF with SAH, it was observed the same change in $\mathrm{SaO}_{2}$ (Table 3).

Table 3 - Average and standard deviation for the variables of the study - IRC group with hypertension $(\mathrm{n}=14)$.

\begin{tabular}{|c|c|c|c|c|c|c|}
\hline & & \multicolumn{4}{|c|}{ Anesthetic } & \multirow{3}{*}{ Significance } \\
\hline & \multicolumn{3}{|c|}{ ACV } & \multirow{2}{*}{\begin{tabular}{|c|} 
ASV \\
Average \\
\end{tabular}} & \multirow[b]{2}{*}{ DP } & \\
\hline \multicolumn{2}{|c|}{ Variable } & Average & DP & & & \\
\hline \multirow{4}{*}{ FC } & T0 & 73.29 & 11.08 & 73.93 & 13.28 & 0.7505 \\
\hline & T5 & 73.71 & 11.31 & 72.50 & 12.98 & 0.5611 \\
\hline & $\mathrm{T} 15$ & 73.00 & 11.40 & 74.14 & 12.47 & 0.6750 \\
\hline & T30 & 73.93 & 11.89 & 72.64 & 11.66 & 0.3591 \\
\hline \multirow{4}{*}{$\mathrm{SaO}_{2}$} & T0 & 95.93 & 1.98 & 97.07 & 1.21 & 0.0877 \\
\hline & T5 & 97.00 & 1.41 & 95.93 & 1.98 & 0.0417 \\
\hline & T15 & 97.00 & 1.52 & 96.29 & 2.20 & 0.1365 \\
\hline & T30 & 96.43 & 1.70 & 96.71 & 1.59 & 0.5830 \\
\hline \multirow{4}{*}{ PAS } & T0 & 144.07 & 23.26 & 132.50 & 21.22 & 0.0610 \\
\hline & T5 & 142.71 & 25.35 & 134.86 & 22.60 & 0.2066 \\
\hline & $\mathrm{T} 15$ & 143.71 & 23.50 & 134.50 & 23.51 & 0.0651 \\
\hline & T30 & 144.14 & 26.29 & 135.93 & 21.90 & 0.1423 \\
\hline \multirow{4}{*}{ PAD } & T0 & 82.14 & 11.83 & 76.86 & 15.47 & 0.0932 \\
\hline & T5 & 81.21 & 15.33 & 78.00 & 16.40 & 0.4079 \\
\hline & $\mathrm{T} 15$ & 80.71 & 12.83 & 81.07 & 15.90 & 0.9176 \\
\hline & T30 & 82.86 & 14.55 & 79.00 & 15.92 & 0.1579 \\
\hline
\end{tabular}

ACV - local anesthetic with vasoconstrictor; ASV - anesthetic without vasoconstrictor; HR-Heart rate; $\mathrm{SaO}_{2}$ - oximetry; PAS - systolic blood pressure; DBP - Diastolic Blood Pressure; SD - Standard Deviation; T0 - initial time, T5 - 5 minutes after anesthesia; T15 - 15 minutes after anesthesia; T30 - 30 minutes after anesthesia. Significance with $\mathrm{P}<0.05$ by paired $t$ test.

Source: Data from the survey. 
In individuals with $\mathrm{CRF}$, the systemic diseases and even therapy for HD affect the oral cavity, leading to several injuries and even tooth $\operatorname{loss}^{8.11}$. This information warns us on the risk at the time of transplantation to know that these individuals are more susceptible to infections due to frail health or even the impossibility of transplantation due to an infectious process, being critical the infection control ${ }^{8-10,16.17}$. The dental care can be done through periodic maintenance to the dentist with the control of oral microbiote ${ }^{12}$.

The mean age of the subjects of the present study was $47.85 \pm 9.76$ years, in contrast with ages above 60 years of age reported in other studies ${ }^{7,18,19}$, demonstrating that not only the elderly population is being affected by this disease. In relation to gender, most individuals with CRF was $75 \%$ (15) men.

Individuals with CRF under HD suffer for years with the disease and its treatment, which leads them to develop various physical, psychological and social problems, directly affecting the quality of life of these, their families, and possibly of society as a whole ${ }^{5,20-24}$.

Among the most frequent comorbidities is $\mathrm{SAH}^{2,4-7}$, which in this study was associated with CRF in $70 \%$ (14) of the individuals, consistent with the constancy already described in the literature ${ }^{6.7}$. In relation to the incidence of DM in the present study, 35\% (7) of individuals reported having the disease, being the second most frequently associated comorbidity, as well as previously described in the literature ${ }^{2,5-8,25}$. Such information alert to cases of more invasive procedures, taking into account the possible need for control of SAH and the relationship of the DM on the healing repair.

The only statistically significant difference in the study, in T5 for individuals with IRC or IRC associated with SAH, where the average oxygenation in individuals was greater when local anesthetic with vasoconstrictor was used, possibly presents no clinical relevance and comes from relatively small sample. This observation is corroborated by the absence of statistical difference in relation to HR, SBP and DBP, suggesting that dental interventions in individuals with CRF who require small number of local anesthetics with or without vasoconstrictor are within a threshold of acceptable security. This recommendation is in agreement with authors who advocate the rational use of local anesthetic, taking into consideration factors such as dose, technique used, power, latency, pharmacokinetics and toxicity ${ }^{26,27,28}$. However, its use in individuals with some type of heart disease should be cautious ${ }^{14}$, considering that the presence of vasoconstrictor is important since it prolongs the action of anesthetic and decreases the toxicity of the same ${ }^{14.29}$.

It is also emphasized that the frequent association of individuals with $\mathrm{CRF}$ under $\mathrm{HD}$ to $\mathrm{SAH}$, widely described in the literature ${ }^{4-7}$, requires that multiple care be considered such as consideration to heparin used in HD, the control of systemic arterial pressure and the use of anesthetics with or without vasoconstrictor, according to the type and duration of the dental procedure proposed ${ }^{14}$.

Moreover, the present study demonstrates that possible variations in systemic parameters $\left(\mathrm{SaO}_{2}, \mathrm{HR}, \mathrm{SBP}\right.$ and $\left.\mathrm{DBP}\right)$ may be associated with the pain of anesthetic injection ${ }^{30}$. However, it is important to consider the limitation of this study by use of maximum 1 anesthetic cartridge $(1.8 \mathrm{ml})$, in respect to the literature data, which show that higher doses of local anesthetic with vasoconstrictor should be used sparingly ${ }^{14}$.

The findings of this study emphasize the safety of the use of anesthetics, with or without vasoconstrictors, as long as in small quantities, in individuals with CRF in hemodialysis treatment with or without SAH associated.

\section{Conclusion}

In this study it is concluded that the use of local anesthetics with or without vasoconstrictor showed no influence on SBP, DBP, $\mathrm{HR}$ and $\mathrm{SaO}_{2}$, to be administered by the proposed technique in individuals with CRF associated or not to SAH.

\section{References}

1. Moody WE, Edwards NC, Madhani M, Chue CD, Steeds RP, Ferro CJ, Townend JN. Endothelial dysfunction and cardiovascular disease in earlystage chronic kidney disease: cause or association? Atherosclerosis 2012;223(1)86-94. doi: 10.1016/j.atherosclerosis.2012.01.043.

2. Harada PH, Canziani ME, Lima LM, Kamimura M, Rochitte CE, Lemos MM, et al. Pericardial fat is associated with coronaryartery calcification in non-dialysis dependent chronic kidney disease patients. PLoS One. 2014;9(12). doi: 10.1371/journal.pone.0114358.

3. U.S. Renal Data System. USRDS 2013 Annual Data Report: Atlas of Chronic Kidney Disease. Bethesda: National Institutes of Health, National Institute of Diabetes and Digestive and Kidney Diseases; 2016.

4. Sesso RC, Lopes AA, Thomé FS, Lugon JR, Martins CT. Brazilian Chronic Dialysis Survey 2016. J Bras Nefrol 2017;39(3):261-6. doi: http://dx.doi.org/10.5935/01012800.20170049

5. Greffin S, André MB, Matos JPS, Kang HC, Jorge AJL, Rosa MLG, et al. Chronic kidney disease and metabolic syndrome as risk factors for cardiovascular disease in a primary care program. J Bras Nefrol 2017;39(3):246-52. doi: 10.5935/0101-2800.20170040.

6. Rottembourg J, Rostoker G. Use of intravenous iron supplementation in chronic kidney disease: Interests, limits, and recommendations for a better practice. NephrolTher. 2015;11(7):531-42.

7. Salvador González B, Rodríguez Pascual M, RuipérezGuijarro L, Ferré González A, Cunillera Puertolas O, Rodríguez Latre LM. Chronic kidney disease in Primary Health Care: prevalence and associated risk factors. Aten Primaria 2015;47(4):236-45. doi: 10.1016/j.aprim.2014.06.003.

8. Paula EA, Costa MB, Colugnati FA, Bastos RM, Vanelli CP, Leite $\mathrm{CC}$, et al. Strengths of primary healthcare regarding care provided for chronic kidney disease. Rev Latinoam Enferm. 2016;24(0):e2801. doi: https://dx.doi.org/10.1590\% 2F1518-8345.1234.2801

9. Schmalz G, Kauffels A, Kollmar O, Slotta JE, Vasko R, Müller GA, et al. Oral behavior, dental, periodontal and 
microbiological findings in patients undergoing hemodialysis and after kidney transplantation. BMC Oral Health 2016;16(1):72. doi: 10.1186/s12903-016-0274-0.

10. Buhlin $\mathrm{K}$, Bárány $\mathrm{P}$, Heimbürger $\mathrm{O}$, Stenvinkel $\mathrm{P}$, Gustafsson A. Oral health and pro-inflammatory status in end-stage renal disease patients. Oral Health Prev Dent 2007;5(3):235-44.

11. Tramini P, Montal S, Valcarcel J. Tooth loss and associated factors in long-term institutionalised elderly patients. Gerodontology 2007;24(4):196-203.

12. Pallos D, Leão MV, Togeiro FC, Alegre L, Ricardo LH, Perozini $C$, et al. Salivary markers in patients with chronic renal failure. Arch Oral Biol 2015;60(12):1784-8. doi: 10.1016/j.archoralbio.2015.09.008.

13. Maruthingal S, Mohan D, Maroli RK, Alahmari A, Alqahtani A, Alsadoon M. A comparative evaluation of $4 \%$ articaine and $2 \%$ lidocaine in mandibular buccal infiltration anesthesia: a clinical study. J IntSocPrev Community Dent 2015;5(6):4639 doi: 10.4103/2231-0762.167717.

14. Brito F, Almeida S, Figueredo CM, Bregman R, Suassuna $\mathrm{JH}$, Fischer RG. Extent and severity of chronic periodontitis in chronic kidney disease patients. J Periodontal Res 2012;47(4):426-30. doi: 10.1111/j.1600-0765.2011.01449.x.

15. Malamed SF. Handbook of local anaesthesia. Missouri: Mosby Year Book; 1994.

16. Chang GH, Tsai MS, Liu CY, Lin MH, Tsai YT, Hsu CM, Yang YH. End-stage renal disease: a risk factor of deep neck infection - a nationwide follow-up study in Taiwan. BMC Infect Dis 2017;17 (1):424. doi: 10.1186/s12879-017-25315.

17. Araújo MV, Hong BY, Fava PL, Khan S, Burleson JA, Fares G, et al. End stage renal disease as a modifier of the periodontal microbiome. BMC Nephrol 2015;16:80. doi: https://dx.doi.org/10.1186\%2Fs12882-015-0081-x

18. Torres-Lagares D, Serrera-Figallo MÁ, Machuca-Portillo G, Corcuera-Flores JR, Machuca-Portillo C, Castillo-Oyagüe R, et al. Cardiovascular effect of dental anesthesia with articaine (40 $\mathrm{mg}$ with epinefrine $0,5 \mathrm{mg} \%$ and $40 \mathrm{mg}$ with epinefrine 1 $\mathrm{mg} \%$ ) versus mepivacaine (30 $\mathrm{mg}$ and $20 \mathrm{mg}$ with epinefrine $1 \mathrm{mg} \%$ ) in medically compromised cardiac patients: a crossover, randomized, single blinded study. Med Oral Patol Oral Cir Bucal 2012;17(4):e655-60.

19. Cherchiglia MA, Machado EL, Szuster DAC, Andrade ELG, Acúrcio FA, Caiaffa WT, et al . Perfil epidemiológico dos indivíduos em terapia renal substitutiva no Brasil, 2000-2004. Rev Saúde Pública 2010;44(4):639-49.

20. Costa FG, Coutinho MPL, Santana IO. Insuficiência renal crônica: representações sociais de indivíduos com e sem depressão. Psico-USF 2014;19(3):387-98. doi: http://dx.doi. org/10.1590/1413-82712014019003002.

21. Moreira JM, Matta SM, Kummer AR, Barbosa IZ, Teixeira AL, Silva ACS. Transtornos neuropsiquiátricos e doenças renais: uma atualização. J Bras Nefrol 2014;36(3):396-400. doi: 10.5935/0101-2800.20140056

22. Gesualdo GD, Duarte JG, Zazzetta MS, Kusumota L, Say KG, Pavarini SCI, et al. Cognitive impairment of patients with chronic renal disease on hemodialysis and its relationship with sociodemographic and clinical characteristics. Dement Neuropsychol 2017;11(3):221-6. doi: http://dx.doi. org/10.1590/1980-57642016dn11-030003

23. Vides MC, Martins MRI. Bone pain assessment in patients with chronic kidney disease undergoing hemodialysis. Rev Dor 2017; 18 (3):245-49. doi: http://dx.doi.org/10.5935/18060013.20170109 .

24. Yu L, Santos BFC, Burdmann EA, Suassuna JHR, Batista PBP. Diretrizes da Associação Médica Brasileira - Sociedade Brasileira de Nefrologia - Insuficiência Renal Aguda 2007 [acesso 3 jan. 2018]. Disponível em https://sbn.org.br/app/ uploads/Diretrizes_Insuficiencia_Renal_Aguda.pdf

25. Hu H, Patel S, Hanisch JJ, Santana JM, Hashimoto T, Bai H, et al. Future research directions to improve fistula maturation and reduce access failure. SeminVasc Surg 2016;29(4):15371. doi: 10.1053/j.semvascsurg.2016.08.005

26. Kim YJ, Moura LM, Caldas CP, Perozini C, Ruivo GF, Pallos $\mathrm{D}$, et al. Evaluation of periodontal condition and risk in patients with chronic kidney disease on hemodialysis. Einstein 2017;15(2):173-7. doi: 10.1590/S1679-45082017AO3867.

27. Bailard NS, Ortiz J, Flores RA. Additives to local anesthetics for peripheral nerve blocks: Evidence, limitations, and recommendations. Am J Health SystPharm 2014;71(5):37385. doi: doi: 10.2146/ajhp130336.

28. Lammers E, Nusstein J, Reader A, Drum M, Beck M, Fowler S. Does the combination of $3 \%$ mepivacaine plain plus $2 \%$ lidocaine with epinephrine improve anesthesia and reduce the pain of anesthetic injection for the inferior alveolar nerve block? A prospective, randomized, double-blind study. J Endod 2014;40(9):1287-92. doi: 10.1016/j.joen.2014.04.015.

29. Maruthingal S, Mohan D, Maroli RK, Alahmari A, Alqahtani A, Alsadoon M. A comparative evaluation of $4 \%$ articaine and $2 \%$ lidocaine in mandibular buccal infiltration anesthesia: a clinical study. J IntSocPrev Community Dent 2015;5(6):4639. doi: 10.4103/2231-0762.167717.

30. Scarparo HC, Maia RN, de Gois SR, Costa FW, Ribeiro TR, Soares EC. Effects of mepivacaine $2 \%$ with epinephrine in the cardiovascular activity of patients undergoing third molar surgery: a prospective clinical study. J Craniofac Surg. 2014;25(1):e9-12. doi: 10.1097/SCS.0b013e3182a2ec06. 